\title{
EFFECTIVENESS OF GOALBALL ATHLETES THROWING IN THE CHILEAN NATIONAL LEAGUE
}

\author{
EFECTIVIDAD DEL LANZAMIENTO DE LOS ATLETAS DE GOALBALL EN LA LIGA \\ NACIONAL DE CHILE
}

\begin{abstract}
Kevin Isaías Campos Campos ${ }^{1}$, Luis Felipe Castelli Correia de Campos², Marcio Pereira Morato ${ }^{3}$, Alessandro Tosim ${ }^{4}$, Mónica Fernández Muñoz ${ }^{5}$, Karina Alarcón Segura ${ }^{1}$, Cristian Luarte Rocha ${ }^{6}$
\end{abstract}

\section{Icastelli@ubiobio.cl}

\author{
${ }^{1}$ Grupo de Investigación en Deporte Adaptado y Paralímpico, Concepción, Chile \\ ${ }^{2}$ Universidad del Bío-Bío, Chillán, Chile \\ ${ }^{3}$ Universidad de São Paulo, São Paulo, Brasil \\ ${ }^{4}$ Confederación Brasileña de Deportes para Discapacitados Visuales, São Paulo, Brasil \\ ${ }^{5}$ Universidad Adventista de Chile, Chillán, Chile \\ ${ }^{6}$ Universidad San Sebastián, Concepción, Chile
}

Original submission: 2021-04-17 Resubmitted: 2021-08-27 Accepted: 2021-10-12

Published: 2021-11-16

Doi: https://doi.org/10.15517/pensarmov.v19i2.46651

\begin{abstract}
Goalball is a collective Paralympic sport with oppositional characteristics but without invasion by the athletes that, despite requiring great physical condition in offensive and defensive actions, is also identified as a tactical sport, where the administration of technique in the various game situations determines success in competition. The objective of the study was to analyze the effectiveness of the attack of the Chilean National Goalball League, according to type of shot and trajectory. Four Goalball matches of the final phase of a national tournament were filmed. For this, a digital camera was used behind an arch located in height. The matches were analyzed following the diagrams proposed by Morato et al. (2016) and Morato (2012). The front throw (FRO) was used the most (88.9\%) with an effectiveness rate of $6.2 \%$. Longer trajectories were made in short
\end{abstract}


diagonals (SD) and parallel (PA) (31.3\% and 23.2\%, respectively). The FRO throw was directed in SD (34.5\%) and PA (22.4\%), while on the other hand, the spinning throws (SP) were directed preferably in PA (30.4\%) and SD (29.1\%). The FRO throw was more effective in PA (10.6\%), whereas the SP throw was more effective in the middle diagonal (MD) (12.5\%). The lateral positions execute throws, preferably $\mathrm{FRO}$, but in defense the central positions are protagonists. Throws are most effective when they are directed in PA and SD.

Keywords: goalball, performance, team sports, athletic leagues, Chile.

\section{RESUMEN}

El Goalball es un deporte paralímpico colectivo con características de oposición, pero sin invasión por parte de los atletas que, a pesar de requerir gran condición física en las acciones ofensivas y defensivas, también se identifica como un deporte táctico, en donde la administración de la técnica en las diversas situaciones del juego, determinan el éxito en la competencia. El objetivo del estudio fue analizar la efectividad del ataque de la Liga Nacional de Goalball de Chile, según tipo de lanzamiento y trayectoria. Se filmaron cuatro partidos de Goalball de la fase final de un torneo nacional. Para ello se utilizó una cámara digital posicionada detrás de un arco ubicada en altura. Para el análisis de los partidos se utilizaron los diagramas propuestos por Morato et al. (2016) y Morato (2012). Los datos se transcribieron de forma computacional a una planilla para luego ser analizados descriptivamente. El lanzamiento frontal (FRO) fue el que más se utilizó $(88.9 \%)$ con una tasa de efectividad del 6.2\%. Se realizaron trayectorias más largas en diagonales cortas (SD) y paralelas (PA) (31.3\% y 23,2\%, respectivamente). El lanzamiento de FRO se dirigió en SD (34.5\%) y PA (22.4\%), mientras que, por otro lado, los lanzamientos con giro (SP) se dirigieron preferentemente en PA (30.4\%) y SD (29.1\%). El lanzamiento FRO fue más efectivo en PA (10.6\%), mientras que el lanzamiento SP fue más efectivo en diagonales medias (MD) (12.5\%). Las posiciones laterales ejecutan lanzamientos, preferentemente FRO, pero en defensa las posiciones centrales son protagonistas. Los lanzamientos son más efectivos cuando se dirigen en PA y SD.

Palabras clave: goalball, desempeño, deportes en equipo, ligas atléticas, Chile.

\section{INTRODUCTION}

The origin of goalball dates back to 1946 where, after the Second World War, the Austrian Hans Lorenzen and the German Sepp Reindle created this sport exclusively for visually impaired 
people with sports classification B1, B2, and B3. The main objective of the game is for the sound ball to cross the opponent's goal line by throwing, while the other team tries to prevent it through blocks with their body (Amorim, Bothelho, Sampaio, Molina \& Corredeira, 2010; International Blind Sports Federation [IBSA], 2020a).

The competitive level of the modality has been increasing. In the last five years, 22 countries have joined the male division and 11 countries the female division. Registering a total of 94 male countries and 54 female countries that officially practice this sport worldwide (IBSA, 2020b).

The growth of participants and countries is one of the factors of the competitive increase in the modality, which is why sports preparation, referring to the set of systems related to the optimal development of the modality, is fundamental in the three systems that compose it: (1) competition; (2) training; and (3) complementary factors, since they must act jointly and assist in the preparation of athletes (Borin, Gomes \& Santos, 2007; Gomes, 2009).

In the competition system, the concept of competitive modeling is mentioned, which is basically associated with all the aspects that involve the competition: the tournament regulations, the physical demand imposed on the athletes, as well as the quantification of technical-tactical actions during matches (Platonov, 2008).

On the other hand, the training system is considered the main focus in the athlete's preparation, where the technical team must consider all the mechanisms that represent a systematized and structured process for sports training, respecting the principle of specificity of the modality, individuality, overload, continuity, volume and intensity (Gomes, 2009).

The third system, called "complementary factors," considers all the resources used to optimize the athlete's preparation after the training session or to maintain performance during the competition period (Santos, 2019).

Goalball is a collective sport that has oppositional characteristics, but without invasion by the athletes, being an acyclic sport where aerobic metabolism is predominant and alactic anaerobic metabolism is a determining factor for competitive success, that is, it requires a high level of muscular power, since its actions are explosive and occur in less than 10 seconds (Alves et al., 2018; Tosim et al., 2020; Campos et al., 2020). It is also identified as a tactical sport (game system), where the administration of the technique (spatial orientation, temporal and auditory perceptions) in the various situations of the game determine success in the competition (Morato, 2012; Morato, Simöes, \& Gaviäo, 2012; Gómez \& Tosim, 2016). Regarding the above, Nascimento \& Camargo (2012) suggest that a good throw (with power, direction and technique) guarantees the success of the team, so we must consider this terrain in detail, in order to improve and perfect the technique of the practitioners. 
Performance analysis is essential to advance understanding of the game context (technique and tactics) in order to improve future results during training or competition (Trapp, 2017; McGarry, 2009). It should include all research that analyzes sports performance in real competition or training of the particular sport (Hughes \& Bartlett, 2002).

In conventional sports, various studies have been carried out to analyze the biomechanics of shooting in soccer (Sinclair et al., 2014), and the throw in beach handball (Dol, Onetto, Carbonell \& González, 2020), as well as in basketball (Li \& Feng, 2020). In Paralympic sports, studies have been carried out that analyze the boccia throw (Reina, Domínguez-Díez, Urbán \& Roldán, 2018), the shoot in 5-a-side football (Gamonales, León, Muñoz, González \& Ibáñez, 2018) and, particularly, in goalball, studies were identified that analyzed the speed of the throw (Campos et al., 2020), but there is still a lack of studies that analyze the effectiveness of the types of throws and their respective trajectories during official matches in a national tournament.

Regarding the above, Trapp (2017) developed a software proposal based on specialized data analysis and knowledge extraction algorithms, proving to be an optimal tool to evaluate the specific performance of goalball athletes. These sport-specific analysis data are added to those of Morato, Piva da Cunha, Henrique, Pinguelli \& Gavião (2016) who made an analysis proposal based on an observation sheet on which this research is based. Given the scarce scientific evidence on the analysis of the competitive performance of the goalball sport, the need arises to analyze the effectiveness of the attack in goalball athletes in a Chilean league tournament.

Thus, the objective of this study was to analyze the effectiveness of the attack of the Chilean National Goalball League, according to the type of throw and trajectory, data which may allow coaches to promote the most effective actions, in attack and defense situations, during training sessions and competitions.

\section{METHODOLOGY}

\section{Study design}

The study presented a quantitative, cross-sectional observational design approach with a descriptive scope. For the development of the study, four male goalball teams participated, the official matches of the playoff phase were recorded, which were two semi-final matches, a third and fourth place match and the final of the national goalball league, which is one of the main tournaments of this sport in Chile. Finally, 24 athletes with a total of 710 throws were analyzed.

Before start the study, the recordings were authorized by the organization of the event, and by the coaches and athletes of the teams that participated in the playoff. All athletes signed an informed consent, complying with the standards established in the Declaration of Helsinki. 


\section{Procedures}

For the development of the study, a Canon EOS Rebel T6® digital camera was used, positioned behind an arch with a 1.6 meter QZSD-Q999® monopod tripod on a 1.5 meter platform to cover the widest panorama of the matches. Four matches were recorded, the starting and ending points being the sound of the central referee, with an uninterrupted recording during the game.

For the analysis of the matches, the diagram proposed by Morato et al. (2016) was used using the origin sectors determined by the first touch of the thrown ball and the destination sector determined when the ball reached the front line to the orientation area or was blocked by a defender (Figure 1).

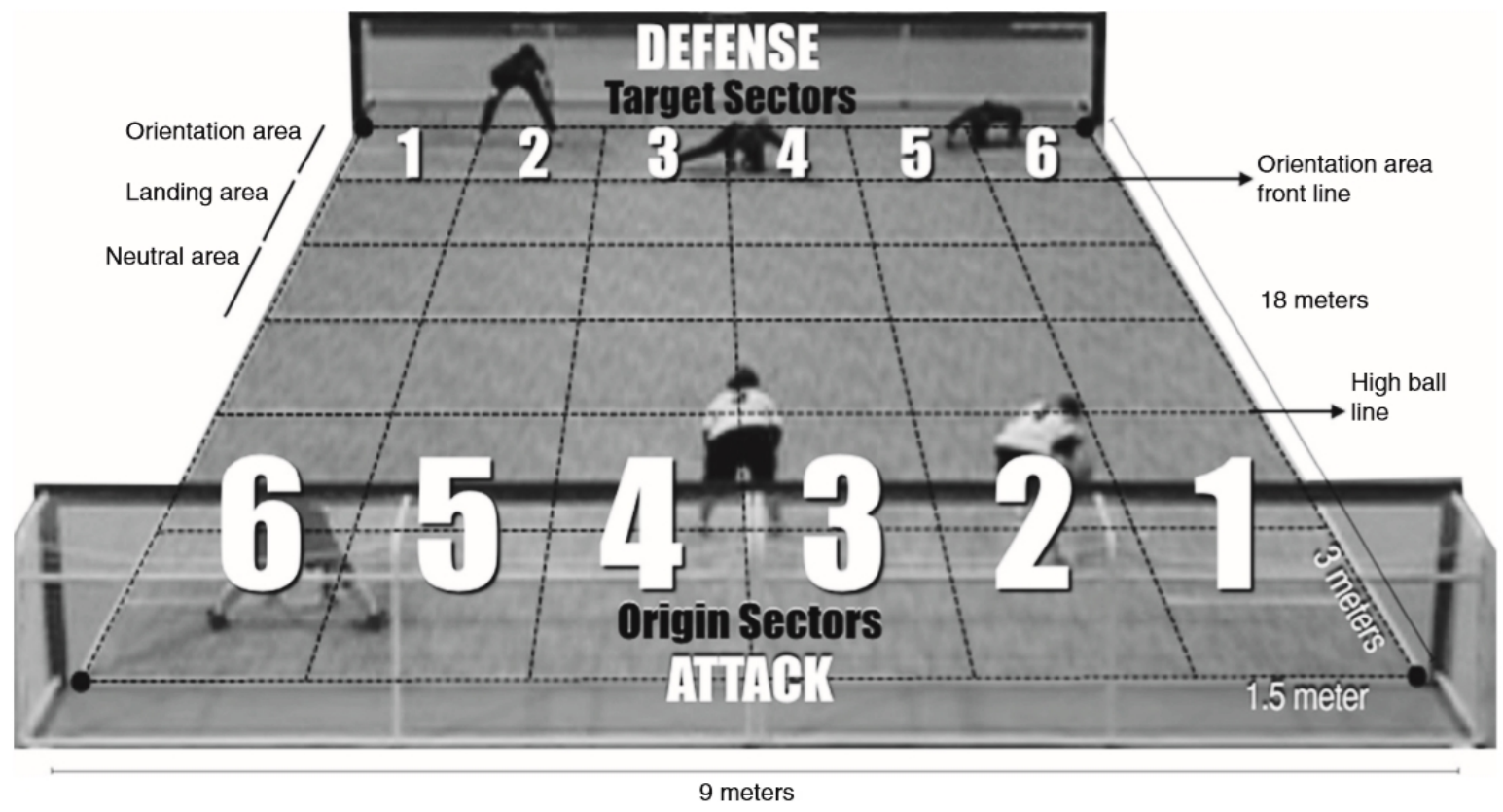

Figure 1. Goalball court diagram and its origin and target sectors. Source: Morato et al. (2016) ${ }^{1}$.

The analysis of the effectiveness of the throws, depending on the trajectory and technique used (frontal or spin), was carried out according to the format proposed by Morato (2012) (figure 2).

\footnotetext{
${ }^{1}$ Figure retrieved from: Morato, M., Piva da Cunha, O., Henrique, D., Pinguelli, T. \& Gavião, J. (2016). Development and evaluation of an observational system for goalball match analysis. Revista Brasileira de Ciências do Esporte, 39(4), 398-407. doi: https://doi.org/10.1016/i.rbce.2016.08.002. This work is licensed under a Attribution-NonCommercial-NoDerivatives 4.0 International (CC BY-NC-ND 4.0)
} 


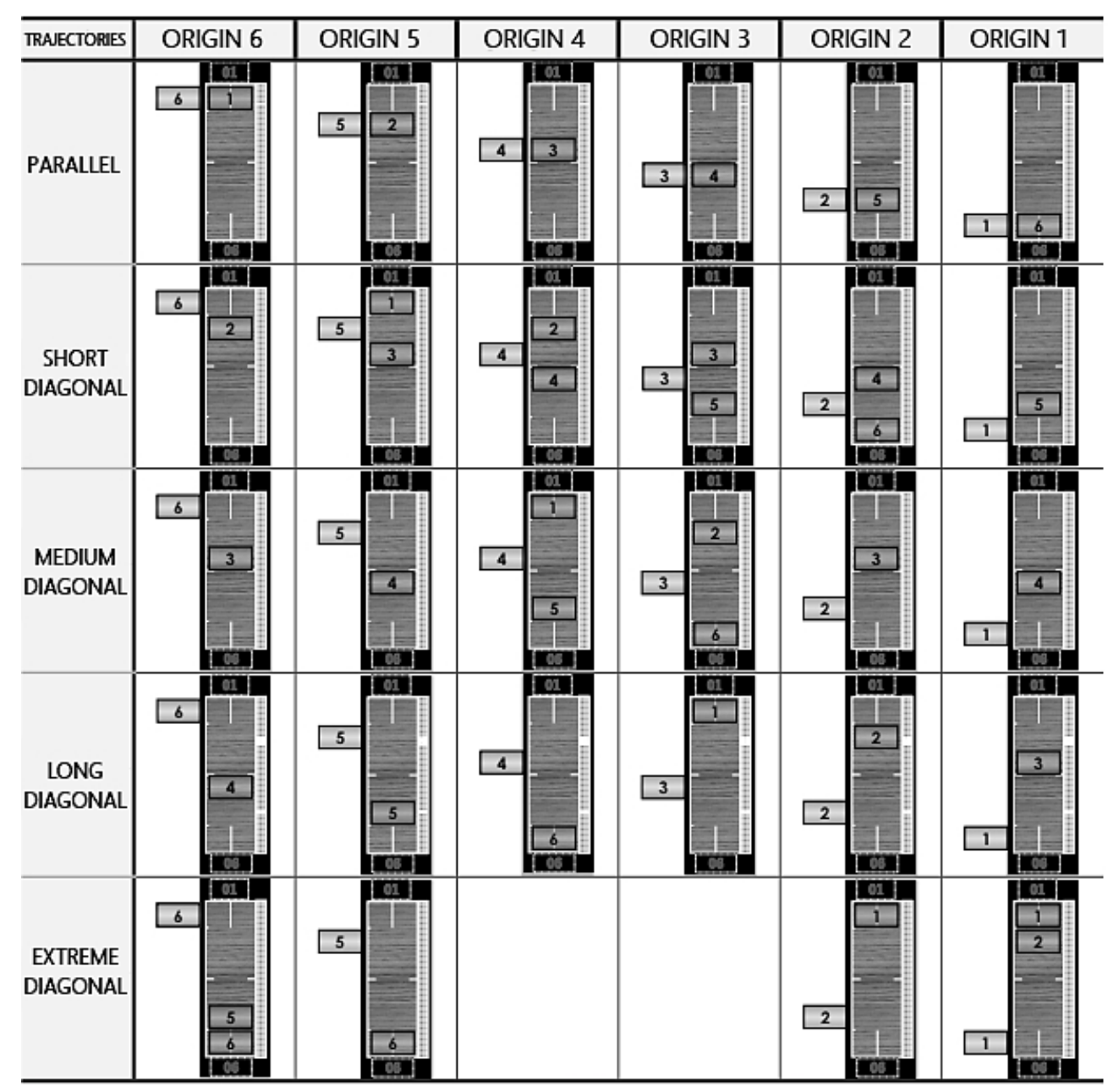

Figure 2. Ball trajectory categories in goalball according to origin and target sectors. Source: Morato (2012).

\section{Statistical analysis}

To demonstrate reliability and concordance in the observed data, the analysis was performed by three experts in video data collection procedures associated with sports performance.

To check the rank of inter-observer reliability, the Intraclass Correlation Coefficient between pitching trajectory, pitch types, and effectiveness, with a total sample of 710 pitches in the playoff phase $(I C C=1.00 ; 95 \% \mathrm{Cl}=1.00-1.00 ; p=0.000)$ was used. Once a perfect concordance strength was confirmed, the Shapiro-Wilk test was used to verify the normality of the data. Subsequently, a descriptive analysis was carried out.

The data were transcribed into a computational spreadsheet, to be presented through mean $(\overline{\mathrm{x}})$, standard deviation (sd), absolute values and percentage (\%). The descriptive statistical analysis and its graphic representation were performed using GraphPad Prism® 8.0 software. 


\section{RESULTS}

Table 1 shows the descriptive values according to the type of throw: frontal (FRO) and spin $(\mathrm{SP})$. The throw between legs $(\mathrm{BL})$ was not considered, as no $\mathrm{BL}$ throws were made during the competition. It was observed that the FRO throw during the 3rd and 4th place match represented $28.03 \%$ of the total FRO throws of the knockout phase, being higher than the rest of the matches; on the other hand, the SP throw was mostly executed in the final match, with $10.4 \%$ of the throws made in the knockout phase.

\section{Table 1.}

Description according to type of throwing

\begin{tabular}{|c|c|c|c|c|c|c|}
\hline $\begin{array}{l}\text { Throwing } \\
\text { technique }\end{array}$ & $\begin{array}{l}\text { SF } 1 \\
\text { n (\%) }\end{array}$ & $\begin{array}{l}\text { SF } 2 \\
\text { n (\%) }\end{array}$ & $\begin{array}{c}3^{\text {rd }} \text { and } 4^{\text {th }} \\
\text { place } \\
n(\%)\end{array}$ & $\begin{array}{l}\text { Final } \\
\text { n (\%) }\end{array}$ & $\begin{array}{c}\text { TOTAL } \\
\text { N (\%) }\end{array}$ & $\overline{\mathbf{x}} \pm \mathbf{s d}$ \\
\hline FRO & $\begin{array}{c}138 \\
(100 \%)\end{array}$ & $\begin{array}{c}157 \\
(96.9 \%)\end{array}$ & $\begin{array}{c}199 \\
(100 \%)\end{array}$ & $\begin{array}{c}137 \\
(64.9 \%)\end{array}$ & $\begin{array}{c}631 \\
(88.9 \%)\end{array}$ & $157.8 \pm 29$ \\
\hline SP & $\begin{array}{c}0 \\
(0.0 \%)\end{array}$ & $\begin{array}{c}5 \\
(3.1 \%)\end{array}$ & $\begin{array}{c}0 \\
(0.0 \%)\end{array}$ & $\begin{array}{c}74 \\
(35.1 \%)\end{array}$ & $\begin{array}{c}79 \\
(11.1 \%)\end{array}$ & $19.7 \pm 36.2$ \\
\hline TOTAL & 138 & 162 & 199 & 211 & 710 & $177.5 \pm 33.6$ \\
\hline
\end{tabular}

The trajectory of the throw, regarding origin sector and destination sector, is described below in Table 2. It was observed that the full-back positions originated a greater number of throws, being mostly defended by the central positions (S3 and S4). When the throws were directed towards peripheral positions, a high percentage of OUT throws was evidenced. 
Table 2.

Description of throwing by origin sector (OS) and destination sector (DS)

\begin{tabular}{cccccccc}
\hline \multirow{2}{*}{ Sector } & $\begin{array}{c}\text { S1 } \\
\mathbf{n}(\%)\end{array}$ & $\begin{array}{c}\text { S2 } \\
\mathbf{n}(\%)\end{array}$ & $\begin{array}{c}\text { S3 } \\
\mathbf{n}(\%)\end{array}$ & $\begin{array}{c}\text { S4 } \\
\mathbf{n}(\%)\end{array}$ & $\begin{array}{c}\text { S5 } \\
\mathbf{n}(\%)\end{array}$ & $\begin{array}{c}\text { S6 } \\
\mathbf{n}(\%)\end{array}$ & $\begin{array}{c}\text { OUT } \\
\mathbf{n}(\%)\end{array}$ \\
\hline \multirow{2}{*}{ OS } & $128(18 \%)$ & 127 & 102 & 53 & 146 & 154 & - \\
& & $(17.9 \%)$ & $(14.4 \%)$ & $(7.5 \%)$ & $(20.6 \%)$ & $(21.7 \%)$ & \\
\multirow{2}{*}{ DS } & 72 & 88 & $142(20 \%)$ & 117 & 102 & 62 & 127 \\
& $(10.1 \%)$ & $(12.4 \%)$ & & $(16.5 \%)$ & $(14.4 \%)$ & $(8.7 \%)$ & $(17.9 \%)$
\end{tabular}

Note. OS - Origin sector; DS - Destination sector; S1 - Sector; S2 - Sector 2; S3 - Sector 3; S4

- Sector 4; S5 - Sector 5; S6 - Sector 6. Source: the authors

In Figure 3, the throw trajectory data (FRO and SP) are presented according to the description by Morato (2012). This indicates that athletes preferably use short trajectories (PA and $\mathrm{SD}$ ), in the FRO and SP technique (see Figure 2).

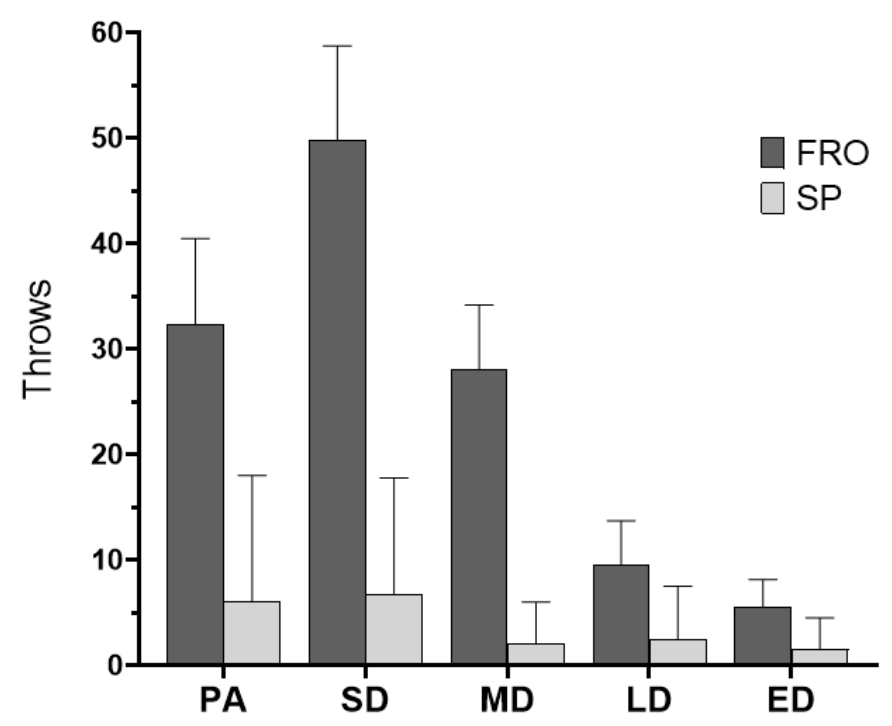

Figure 3. Throwing trajectory. Note. FRO - Frontal; SP - Spin; PA - Parallel; SD - Short Diagonal; MD - Medium Diagonal; LD - Long Diagonal; ED - Extreme Diagonal. Source: the authors

Table 3 shows the effectiveness of FRO and SP throws according to trajectory. The results show that the athletes are more effective in short-distance trajectories (PA, SD and MD) for both throwing techniques. In addition, $89.9 \%$ of correctly executed SP throws were made, representing a higher value compared to FRO throws $(81.1 \%)$. With regard to the efficiency of the throws, the 
FRO technique obtained $6.2 \%$ efficiency, whereas with the SP technique $3.8 \%$ of the throws culminated in a goal. When we compare the OUT throws, we observe that the FRO technique obtained higher values compared to the SP throw (18.9\% vs. $10.1 \%)$.

Table 3.

Effectiveness according to type of throwing and trajectory

\begin{tabular}{|c|c|c|c|c|c|c|}
\hline \multirow{2}{*}{$\begin{array}{l}\text { Throwing } \\
\text { trajectory }\end{array}$} & \multicolumn{2}{|c|}{ FRO } & \multicolumn{2}{|c|}{ SP } & \multicolumn{2}{|c|}{ TOTAL } \\
\hline & $\begin{array}{c}\text { Total } \\
(n=631)\end{array}$ & $\begin{array}{c}\mathbf{G} \\
(n=39)\end{array}$ & $\begin{array}{c}\text { Total } \\
(n=79)\end{array}$ & $\begin{array}{c}G \\
(n=3)\end{array}$ & $\begin{array}{c}\text { Total } \\
(n=710)\end{array}$ & $\begin{array}{c}G \\
(n=42)\end{array}$ \\
\hline PA (n) & $\begin{array}{c}141 \\
(22.3 \%)\end{array}$ & $\begin{array}{c}15 \\
(10.6 \%)\end{array}$ & $\begin{array}{c}24 \\
(30.4 \%)\end{array}$ & $2(8.3 \%)$ & $\begin{array}{c}165 \\
(23.2 \%)\end{array}$ & $\begin{array}{c}17 \\
(10.3 \%)\end{array}$ \\
\hline SD (n) & $\begin{array}{c}199 \\
(31.5 \%)\end{array}$ & $14(7.0 \%)$ & $\begin{array}{c}23 \\
(29.1 \%)\end{array}$ & $0(0.0 \%)$ & $\begin{array}{c}222 \\
(31.3 \%)\end{array}$ & $14(6.3 \%)$ \\
\hline MD (n) & $\begin{array}{c}112 \\
(17.7 \%)\end{array}$ & $6(5.4 \%)$ & $8(10.1 \%)$ & $\begin{array}{c}1 \\
(12.5 \%)\end{array}$ & $\begin{array}{c}120 \\
(16.9 \%)\end{array}$ & 7 (5.8\%) \\
\hline LD (n) & $38(6.0 \%)$ & $2(5.3 \%)$ & $\begin{array}{c}10 \\
(12.7 \%)\end{array}$ & $0(0.0 \%)$ & $48(6.8 \%)$ & $2(4.2 \%)$ \\
\hline ED (n) & $22(3.5 \%)$ & $2(9.1 \%)$ & $6(7.6 \%)$ & $0(0.0 \%)$ & $28(3.9 \%)$ & $2(7.1 \%)$ \\
\hline Out (n) & $\begin{array}{c}119 \\
(18.9 \%)\end{array}$ & - & $8(10.1 \%)$ & - & $\begin{array}{c}127 \\
(17.9 \%)\end{array}$ & - \\
\hline
\end{tabular}

Note. FRO - Frontal; SP - Spin; G - Goal. Source: the authors.

\section{DISCUSSION}

The objective of this study was to analyze the effectiveness of the attack of the Chilean National Goalball League, according to the type of throw and trajectory, finding an average of 177.5 \pm 33.6 throws per game, achieving an effectiveness of $5.9 \%$. The athletes opted for the FRO throw $(88.9 \%)$ with a $6.2 \%$ effectiveness rate compared to the SP throw $(11.1 \%)$ with a $3.8 \%$ effectiveness. Defining that the most used throw is the FRO, with more effectiveness, but also with a greater probability of sending the ball OUT, compared to the SP throw, which presents a higher percentage of shots in play (correctly executed) (89.9\%). However, SP throws were less 
effective-this may be due to the decrease in throwing speed as a result of low technical effectiveness by the players (Morato, Menezes, Fonseca \& Furtado, 2018).

When we talk about the path chosen for the attack, we find preferences for SD $(31.3 \%)$ and PA (23.2\%). But when we analyze the trajectory by type of throws, the results show us that the athletes who performed FRO throws executed more SD and PA (34.5\% and $22.4 \%$, respectively), while the SP throws were preferably directed towards PA (30.4\%) and SD (29.1\%).

Analyzing the trajectory effectiveness by type of throw, we visualize that the PA trajectory presents an effectiveness rate of $10.6 \%$ in the FRO throw. The SP throw, on the other hand, presents a greater effectiveness in the MD trajectory $(12.5 \%)$.

When we compare the results of our study with the literature, we find authors such as Link \& Weber (2018), who analyzed 63 men's goalball matches, participants in the 2012, 2016 Paralympic games and the 2013 and 2015 European Championships. The results show that 184.2 \pm 20.6 throws were made per game, of which $59.4 \%$ corresponded to SP throws with an efficiency of $3.8 \%$. With regard to the trajectory traveled, the players showed a $69.5 \%$ preference for straight (parallel) throws with a goal rate of $4.3 \%$. In our study there was a lower average number of throws per game $(177.5 \pm 33.6)$, coinciding with the preference of the trajectory $(22.4 \%$ in PA) but not with the throwing technique. This may be due to the complexity in technique and tactics involved in the spin throw, requiring great preparation to achieve an efficient execution (Bowerman, Davis, Ford \& Nichols, 2011).

On the other hand, Morato et al. (2018) studied the probability of scoring a goal in elite goalball athletes. To do so, they analyzed 1341 throws by male players from 10 randomly selected matches from the 2008 Beijing Paralympic Games. The results highlight that the most used trajectories were DC (36\%) and PA (26\%) with an effectiveness of $7.1 \%$ and $7.0 \%$ respectively, data similar to those found in our study. This can be explained according to what Morato et al. (2018) point out, that the balls traveling shorter times were more effective, with the DC and PA trajectories being shorter, therefore, the speed of the ball increases. Regarding the above, Campos et al. (2020) evaluated the relationship among different tests, and within them, the estimated maximum force and the throwing time of the goalball, finding an inversely proportional and significant high correlation $(r=-0.80, p=0.008)$, which suggests that strength is a fundamental quality to increase the speed of the throw.

When we compare the results of our study with Morato et al. (2018) we find similar values in the trajectory preference, with SD being the most used (31.3\%), followed by PA (23.2\%). But when we talk about effectiveness, the PA trajectory was more effective than SD (10.3\% vs. $6.3 \%)$. This may be due to the number of throws evaluated compared to one study with another, however 
they show similar data in terms of preferences and effectiveness, where short trajectories stand out as more effective.

In a study carried out by Lehto, Häyrinen, Laitinen \& Collet (2012), the authors analyzed 15 elite men's goalball matches and found an average of $96.4 \pm 6.1$ throws with a higher effectiveness percentage in the winning teams (8.3\% vs. $4.5 \%)$. On the other hand, Jorgić, Aleksandrović, Živković, Utvić \& Popović ( $\underline{2018}$ ) analyzed the quarterfinal matches of the goalball tournament in the Rio 2016 Paralympic games separated into winning and losing teams. The results show that the winning teams presented a total of $97.8 \pm 6.3$ throws with an effectiveness of $5.7 \pm 1.5 \%$, establishing that the winning teams had higher results in all parameters.

Regarding other references, we find Monezi et al. (2018), who analyzed the time movement variables of goalball players in 365 throws, looking at the attack phases, player position and types of throws. Among the results, it is worth highlighting that $85 \%$ of the throws were executed by the fullbacks, also covering longer distances $(1.65 \mathrm{~m})$ than the central ones $(0.31 \mathrm{~m})$ in the preparation and attack phase of the throw. The types of throws SP and BL presented higher values in the variables of movement time (distance traveled, time spent and maximum speed of the player) than the FRO throw, which can be explained by the search for spatial orientation to achieve higher speeds in the post-throwing phase. In the present study, no BL throws were observed in the final stage of the tournament, which could be explained by the fact that the athletes are not stimulated to use these shots during their training sessions, as well as by the need for high technical levels for effectiveness in these types of throws. Athletes choose to perform previously trained actions during official games.

On the other hand, Kornev \& Pravdov (2017) analyzed the final games of the 2014 goalball world championship. Among the findings of their analysis of the men's final, they found that, in both teams, left-back players presented higher throwing percentages (44.4\%), using mostly SD in the attack trajectory (47.4\%) and leaning considerably on SP throws (82.9\%). In addition, the central players carried most of the defensive load.

Muñoz (2013) analyzed 4886 male throws made in the 2009 European championship of national goalball teams. The results establish that the athletes presented an average of 152.68 throws per game with an effectiveness of $7.2 \%$, with the left-back being the one with the highest percentage of offensive actions carried out (42.4\%) followed by the right-back $(40.4 \%)$, with an effectiveness of $2.4 \%$ and $2.2 \%$, respectively. The FRO throw was the most used $(51.9 \%)$, but when we talk about effectiveness by type of attack, we found that the SP throw was more effective (3\%). The results of our study agree that the left-back position (S5 and S6) was the one that 
originated most of the attacks $(20.6 \%$ and $21.7 \%$, respectively), using the FRO throw to a greater extent.

According to the literature we consulted, the results of our study coincide with those of Morato et al. (2018), Link \& Weber (2018) and Kornev \& Pravdov (2017), based on the most used trajectories (PA and SD), there being greater effectiveness in those trajectories. This may be due to what Morato et al. (2018) show, since the faster throws increase the probability of a goal, so the short trajectories (PA and SD) travel fewer routes, which are usually faster throws. Similarly, we found coincidences in the origin of the attack with Muñoz (2013), with the left-back position (S5 and S6) being the one that made the most throws.

It is important to highlight that the results of our study are from the Chilean national championship, where the teams present a low to medium competitive level, therefore, one of the limitations is the lack of preparation of the athletes, with a low level of technique and tactics compared to the literature. As a strength, it stands out as being the first study in Chile focused on analyzing the actions during the official matches in the national goalball tournament.

\section{CONCLUSIONS}

We can conclude that athletes perform FRO throws to a greater extent. This may be due to the complexity in the technique and tactics involved in the SP throw, and this being an important aspect to consider in the athlete's sports preparation.

The effectiveness of the type of throw was greater in the FRO throw than in SP, being directed mainly in SD and PA because of the return time of the throw, since an efficient defensive system, which has greater control of the ball, has greater possibilities of offensive construction. The PA trajectory was more effective. In terms of the position in the game, the left-wing and rightwing players are the athletes who perform most of the defensive actions with similar effectiveness, while the players perform mostly defensive actions.

Due to the fact that a large part of the target sector of the attack ended up going out, athletes perform fewer throws with pronounced diagonals (MD, LD and ED), therefore it is important to have a trained spatial orientation to achieve effective throws in those directions as a result of their complexity.

\section{PERSPECTIVES}

This study provides useful information on performance indicators in goalball attack, providing objective data for coaches that need to be considered in training, in order to improve the competitive performance of their athletes. The analysis of the games is a fundamental pillar in 
advancing the knowledge of the game context to improve future results. The results of the study highlight that the fullbacks were protagonists in the execution of the throws. On the other hand, the central positions carried a greater load in defensive actions, which suggests that the positioning of athletes according to their morphological and functional conditions should be considered. It is suggested that this study should be repeated with a greater number of games and at different competitive levels to verify that the data from our study can be extrapolated, while also considering the defensive actions that are a fundamental element within the modality.

Funding: This research received no external funding.

Acknowledgments: The authors declare thanks to the teachers of the clubs, organizers of the National Goalball League of Chile and the Research Group on Adapted and Paralympic Sport (GIDEPAUSS).

Conflicts of Interest: The authors declare no conflict of interest.

\section{REFERENCES}

Alves, I., Kalva-Filho, C., Aquino, R., Travitzki, L., Tosim, A., Papoti, M. \& Morato, M. (2018). Relationships Between Aerobic and Anaerobic Parameters with Game Technical Performance in Elite Goalball Athletes. Frontiers in Physiology, 9(1636). doi: https://doi.org/10.3389/fphys.2018.01636

Amorim, M., Bothelho, M., Sampaio, E., Molina, J. \& Corredeira, R. (2010). Caracterización de los patrones comportamentales de los atletas con discapacidad visual practicantes de goalball. REIFOP, 13(3), 47-57. Recuperado de https://dialnet.unirioja.es/descarga/articulo/3307412.pdf

Borin, J., Gomes, A. \& Santos, G. (2007). Preparação desportiva: aspectos do controle da carga de treinamento nos jogos coletivos. Journal of Physical Education, 18(1), 97-105. doi: https://doi.org/10.4025/reveducfisv18n1p97-105

Bowerman, S., Davis, R., Ford, S. \& Nichols, D. (2011). Phases of Movement of Goalball Throw Related to Ball Velocity. Research and Practice in Visual Impairment and Blindness, 4(4), 153-159.

Recuperado

de https://www.researchgate.net/publication/287035280 Phases of Movement of Goalball Throw Related to Ball Velocity 
Campos, L. F., Campos-Campos, K., Gajardo-Oñate, J., Luarte, C. E., Teixeira, L. G., Smith. R. \& Petróvna, J. (2020). Caracterización de los deportistas Paralímpicos de Goalball chilenos y asociación entre variables Antropométricas, de Composición Corporal y Fuerza en el Lanzamiento del Balón. Retos, 38(38), 41-44. doi: https://doi.org/10.47197/retos.v38i38.73067

Dol, G., Onetto, V., Carbonell, V. \& González-Ramírez, A. (2020). Analysis of Throwing performance in Elite Women's Beach Handball. Apunts, (141), 49-54. doi: https://doi.org/10.5672/apunts.2014-0983.es.(2020/3).141.06

Gamonales, J., León, K., Muñoz, J., González-Espinosa, S. \& Ibáñez, S. (2018). Validación del IOLF5C para la Eficacia del Lanzamiento en Fútbol para Ciegos. Revista Internacional de Medicina y Ciencias de la Actividad Física y el Deporte, 18(70), 361-381. doi: http://doi.org/10.15366/rimcafd2018.70.010

Gomes, A. (2009). Treinamento Desportivo: Estruturação e Periodização (2a ed.). Brasil: Armetd. Gómez, D. \& Tosim, A. (2016). Maximus Project II: Manual para entrenadores de goalball. Recuperado de https://es.scribd.com/document/404059163/MANUAL-PARAENTRENADORES-DE-GOALBALL-pdf

Hughes, M. \& Bartlett, R. (2002). Performance analysis (editorial). Journal of Sports Sciences, 20(10), 735-737. doi: https://doi.org/10.1080/026404102320675594

International Blind Sports Federation [IBSA]. (2020a). Goalball - General information. Recuperado de https://ibsasport.org/news/

International Blind Sports Federation [IBSA]. (2020b). IBSA Goalball World Rankings: 30 june 2020. Recuperado de https://ibsasport.org/news/

Jorgić, B., Aleksandrović, M., Živković, D., Utvić, N. \& Popović, I. (2018). An analysis of the statistical parameters of goalball matches which might provide team advantage. World Congress of Performance Analysis of Sport XII. Patina, Croatia. https://www.researchgate.net/publication/331907898 An analysis of the statistical para meters of goalball matches which might provide team advantage

Kornev, A. \& Pravdov, M. (2017). Goalball game techniques and tactics. Teoriya I Praktika Fizicheskoy Kultury, 2017(4), 20-22. doi: https://elibrary.ru/item.asp?id=29655521

Lehto, H., Häyrinen, M., Laitinen, T. \& Collet, K. (2012). Match analysis and a comparison between winning and losing teams in men's elite level goalball. World Congress of Performance Analysis of Sport IX. Worcester, England.

Li, Y. \& Feng, T. (2020). The effects of sport expertise and shot results on basketball players' action anticipation. PLoS ONE, 15(1). doi: https://doi.org/10.1371/journal.pone.0227521 
Link, D. \& Weber, C. (2018). Finding the gap: An empirical study of the most effective shots in elite goalball. PLoS ONE, 13(4). doi: https://doi.org/10.1371/journal.pone.0196679

McGarry, T. (2009). Applied and theoretical perspectives of performance analysis in sport: Scientific issues and challenges. International Journal of Performance Analysis in Sport, 9(1), 128-140. doi: https://doi.org/10.1080/24748668.2009.11868469

Monezi, L., Magalhães, T., Morato, M., Mercadante, L., Furtado, O. \& Misuta, M. (2018). Timemotion analysis of goalball players in attacks: differences of the player positions and the throwing techniques. Sports Biomechanics, 18(5), 470-481. doi: https://doi.org/10.1080/14763141.2018.1433871

Morato, M. (2012). Análise do jogo de Goalball: Modelacao e interpretacao dos padroes de jogo nas Paralimpiadas de Pequim 2008 (Tese de Doutorado). Universidad Estadual de Campinas, Brasil.

Morato, M., Menezes, R., Fonseca, S. \& Furtado, O. (2018). Faster balls increase the probability of scoring a goal in female and male elite goalball. Revista Brasileira de Ciências do Esporte, 40(4), 427-434. doi: https://doi.org/10.1016/j.rbce.2018.03.027

Morato, M., Piva da Cunha, O., Henrique, D., Pinguelli, T. \& Gavião, J. (2016). Development and evaluation of an observational system for goalball match analysis. Revista Brasileira de Ciências do Esporte, 39(4), 398-407. doi: https://doi.org/10.1016/j.rbce.2016.08.002

Morato, M., Simöes, M. \& Gaviäo, J. (2012). Os processos auto-organizacionais do goalball. Revista Brasileira de Ciências do Esporte, 34(3), 741-760. doi: https://doi.org/10.1590/S0101-32892012000300015

Muñoz, J. (2013). Análisis de los indicadores del rendimiento competitivo en el Goalball (Tesis de Doctorado). Universidad de Extremadura, España. Recuperado de https://dehesa.unex.es/handle/10662/26

Nascimento, D. \& Camargo, W. (2012). Decodificando o Goalball para Professores-Técnicos de Educaçao Física Adaptada: fundamentos técnicos. Cadernos de Formaçao RBCE, 3(1), 5774. doi: http://revista.cbce.org.br/index.php/cadernos/article/view/1285

Platonov, V. (2008). Tratado Geral de Treinamento Desportivo. Brasil: Phorte.

Reina, R., Domínguez-Díez, M., Urbán, T. \& Roldán, A. (2018). Throwing distance constraints regarding kinematics and accuracy in high-level boccia players. Science and Sports, 33(5), 299-306. doi: https://doi.org/10.1016/j.scispo.2018.03.078

Santos, L. G. (2019). Paracanoagem: Desempenho Esportivo dos Atletas Finalistas de Campeonato Mundial (Tese de Doutorado). Universidad Estadual de Campinas, Brasil. 
Sinclair, J., Fewtrell, D., Taylor, P., Bottoms, L., Atkins, S. \& Hobbs, S. (2014). Three-dimensional kinematic correlates of ball velocity during maximal instep soccer kicking in males. European Journal of Sport Science, 14(8), 799-805. doi: https://doi.org/10.1080/17461391.2014.908956

Tosim, A., Marques, C., Galatti, L., Morato, M., Borin, J. \& Montagner, P. (2020). Desafios e Possibilidades para o Goalball Brasileiro: Concepções a partir de Experiências do Treinador Esportivo que Atua em Clubes Nacionais. Pulsar, 12(1), 64-77. Recuperado de http://pulsar.esef.br/images/stories/arquivos/pdf/revista/Artigos/Volume12 Numero01 202 0/art6.pdf

Trapp, A. (2017). Proposta de um método para análise de informação e tomada de decisão: um estudo de caso no Goalball (Dissertação de Mestrado). Pontifícia Universidade Católica do Paraná, Brasil. Recuperado de http://www.biblioteca.pucpr.br/pergamum/biblioteca/index.php?codAcervo=340539 